\title{
The independence of the judiciary within a European context
}

\author{
by Mario Serio
}

The author considers the need to safeguard judicial independence at both national and European levels.

$\mathrm{I}$ t would not be over-stating the case to say that for some time Europe has experienced a general sentiment that justice should be put on a higher place in the priority list that all political agendas, even at an international level, should have. I for one would like to recall the recent Manifesto for Justice that has been issued in this country, thanks to a common effort made by a coalition of legal organizations and consumer groups.

There may be different underlying reasons why justice is deemed to deserve a more central role in the consideration of both domestic and European institutions and programmes. Some of these may have to do with regional problems reflecting upon the malfunctioning of national legal systems in terms of, for example, insufficient standards for access to justice, or lengthy trials. But there is common ground in what is a largely shared analysis of how the natural and somewhat abstract notion of justice should be translated into every day life via the work done by all relevant parties -namely the view that unless the judiciary is assigned a crucial role and is empowered with reasonable means to satisfactorily meet the public's demands, then all hopes for the improvement of a crippled system seem to be lost.

In the author's opinion, we have to proceed from the assumption that no legal system can ever aspire to acceptance by its daily "consumers" anywhere in a civilized world, if the judiciary is not adequately safeguarded by broad principles which give it and all of its members the certainty that, in doing their jobs, they have nothing to fear or nothing to gain. The core issue in my view is as follows: that each advanced legal system should be built on the idea that judges have to be allowed to work with no other perspective or goal than the performing of their function. This amounts to a basic concept of judicial independence, and my following observations are largely based around this principle.

Obviously, no one can ignore the fact that the debate becomes increasingly heated when attempts are made to identify the concrete measures through which the process aimed at making judicial independence stronger should be conducted. But that is a further element to be dealt with once there is common agreement as to what judicial independence is, and has been historically. Suffice it to say that now we should all contribute to constructing a European manifesto for law that is not aimed at widening political gaps, but at exchanging experiences and proposals in a constructive and unifying way.

First of all, I have to clarify that, when looking at the Italian situation which forms the main focus of this paper, I refer to the judiciary as to the body made up of both judges and public prosecutors according to our constitution, and to the law that depicts only one judicial career for both these categories. As I have said, one characteristic feature of most European legal systems is that the judiciary may suffer no interference from other state bodies and is protected, although in different ways, from any intrusion that is capable of putting undue pressure on its members. If one seeks to trace the historical and political background of this fundamental aspect of European democracies it is easy to recognize the impact that Montesquieu's idea of a modern state has exercised on the matter.

So, the independence of the judiciary should be read as a way to reaffirm that the legislative and administrative powers should not influence the administration of justice that is the process through which justice must be seen to be done, to put it as described by Lord Hewart in the rightly celebrated Rex ${ }_{v}$ Sussex Justices case in 1924. It is a well-known fact that political interference might jeopardize judicial impartiality and, at the same time, undermine the principle according to which all citizens are equal before the law. This is why maintaining an independent judiciary is one of the vital tasks that all democratic states should undertake, because failure to achieve this goal puts the very essence of democracy at risk. This is also why a number of the constitutions adopted by 
European countries contain very stringent and precise provisions touching upon this.

\section{INDEPENDENCE OF THE ITALIAN JUDICIARY}

I will now try to give an illustration of the attitude that the Italian constitution has shown towards the judiciary and also to give a few examples of what factors could weaken its status. In the second part of this article I will concentrate on the implications that the judgments of the European Court of Justice may have on the organisation and functioning of the Member State's national courts, in order to establish whether these decisions may affect, and if so to what extent, the independence and autonomy of the judiciary.

The independence of the Italian judiciary is safeguarded through a solemn declaration contained in article 101 of the constitution which states that "Judges are only subjected to the law". The reference to the law as the only binding force on judges makes it clear that no external or internal interference, strong or prestigious as it may be, could ever be placed on the judiciary and, on the other hand, that the judges have not only the right but also the duty to turn down any such approach and operate only on the basis of what the law says.

Legal authors and the vast majority of judicial opinions agree that a direct consequence stems from the principle set out by article 101 . This is that although the freedom the judiciary enjoys in interpreting the law requires a judge to take into account a series of criteria, such as the literal, the finalistic, the golden rule (as it is called in the common law), Parliamentary debates, , in the end, it is only up to him/her to decide what is the meaning, scope and ambit of a particular disposition or of a broader text. Obviously, such an option is always open to the judicial review at its highest level, by the Corte di Cassazione.

A relevant consequence of this fundamental freedom can be seen in judicial immunity, whether at civil, criminal or disciplinary level, in the process of interpreting the law, provided there is no proof of bad faith or gross negligence. Another constitutional disposition is aimed at re-affirming, beyond any reasonable doubt, the nature of judicial status: article 104 provides that the Italian judiciary gives rise to an autonomous body that is independent on any other power. In order to give effectiveness to the judiciary's independence the constitution has set up the Consiglio Superiore della Magistratura, that is the authority presided over by the President of the Republic, whose members are elected by two-thirds of all professional judges and magistrates, and one third by the two Houses of Parliament. This is the governing authority as far as judges' careers and discipline are concerned.

Another consequence of the protection recognized at constitutional level to Italian judges is that they can only be transferred or removed from office following a decision by the Consiglio Superiore della Magistratura or with their consent. In the framework of the Italian legal system the independence of the judiciary is recognised as being of value in its own right, but is also depicted as a goal to achieve for the benefit of citizens. This implies that if judges have a constitutional right to be independent and not to be deprived of their status, at the same time all citizens have a right to be judged in an independent and unbiased way by the very judge (the so called "natural judge") who, by pre-existing law, should be allocated the case. Therefore, the principle of due process of law has been fixed to make sure that the defendant 's right to a fair hearing is guaranteed and that all judicial proceedings are to be led by an impartial and unbiased judge in accordance with the requirement fixed by Article 6 of the European Convention on Human Rights.

The same principle has another field of application, namely the length of trials, which may not exceed reasonable time limits. If the contrary occurs the state will be held liable to the affected individuals, and the judge responsible for not speeding up the process may be disciplined. Also, it is prescribed that when making their decisions judges have to give reasons, if their orders are not to be quashed by the Corte di Cassazione.

One point should be reiterated - that when speaking of the judiciary the expression comprises both judges and public prosecutors. The constitution also gives public prosecutors the same recognition of independence as that conferred upon the judges. A debate has been going on for a long time in heated terms in Italian political circles as to the possible modification of the situation, and to the feasibility of a system similar to the French model where public prosecutors belong to the executive.

If one tries to summarize the current position of the Italian magistracy, it can be said that its influence over the general context of public life is very wide and deep. This is partly due to the magnitude of the powers with which Italian judges and magistrates are invested, as set out above, but is also partly due to the customary reading of all judgments in the light of political evaluation of their impact and of their authors' intention.

This may not sound reassuring or dignified, and it is also sad. But it would be unrealistic to ignore the turbulence that has affected the relationship between the judiciary and politics over the past few years. This sometimes head-on clash reveals an unenviable and divisive feature that has transformed the political arena into a place where judges risk being defended or accused in relation to their supposed political views rather than for the merit of their decisions. But a very strong barrier in defence of the prerogatives the constitution has devised as a shield has been erected over the years by the Corte Costituzionale, the court that is empowered to quash or repeal any legislative instrument that is found to collide or be inconsistent with the constitution itself. 
On a variety of occasions the Corte Costituzionale has intervened to proclaim the sanctity of the judiciary, and rule that no liability can be incurred by judges in the performing of their duties with the sole exception of patently unjustifiable conduct. The Corte Costituzionale has also stated that all judicial orders may be appealed against before it, particularly if they are not sufficiently grounded in terms of argumentative reasons and of immunity from law errors.

The final impression from this holistic review of the Italian position is that any attempt at reconstruction should always take into consideration what alterations or adjustments to the legal framework the relevant law could bring about. Furthermore, one cannot overlook that today all discussions on judicial topics in Italy must unfortunately come to terms with political implications and innuendos: whether or not this may lead to a growth of awareness of the judiciary's crucial importance as the guardian of individual and social rights remains to be seen. Personally, I doubt very strongly that this will happen because society's loss of confidence in the judiciary is something that needs to be remedied without compromising the constitutional safeguards.

It is worth noting that a Government Bill aimed at judicial reform has been under Parliamentary scrutiny for some time now: the process is far from being finalized, and doubt surrounds its outcome. The spirit of this fiercelycontested reform may be described as an attempt to redefine the ladder of the judicial hierarchy, particularly through the re-introduction of selective contests for the upgrading and promotion for judges and magistrates. This is a very controversial issue that has lead to an unprecedented row between government and judiciary, and there is no easy way to resolve it.

Another controversy at the heart of the reform concerns the definition of the conduct, acts or omissions which give rise to a disciplinary infringement. The Bill moves towards such a definition, making it compulsory for the holder of the public prosecutor's office with the highest responsibility (Procuratore Generale presso la Corte di Cassazione) to proceed with the appropriate indictment. As has been said above, Italy is now being faced with a proposal that exhibits a truly divisive character: it is also a sign that judicial waters are still troubled and it is up to the academics to take upon themselves the burden to try and build a bridge over them.

\section{JUDICIAL INDEPENDENCE AT NATIONAL AND EUROPEAN LEVELS}

Earlier I thought it was necessary to isolate two questions as being of paramount importance in the tackling of the topic, both at national and European level. The first concerns a clear identification of the circumstances that may enable the competent office to promote a disciplinary action against a member of the judiciary for actions committed while in office. Logically, a preliminary question has to be raised regarding whether or not such an initiative should be compelling on the holder of the power, or whether it should be seen as the exercise of a discretionary power which should not be made the object of any possible review (as has been the Italian case so far).

On the same issue it must be asked whether holders of the office for the disciplining and prosecution of members of the judiciary should continue their judicial careers, and so be judges or magistrates themselves, or be wholly independent (for example as members of the Government or representatives of the public interest). In Italy, we have a concurrent assignment of the task to both the head of Public Prosecutors of the Corte di Cassazione (the highest authority of all Italian public prosecutors) and the Minister of Justice. They act separately and independently, and their prerogatives are of a discretionary nature, so they do not have to give reasons if they abstain from making an indictment following an official on individual complaint.

It is a highly controversial question whether, in a country such as Italy where it is compulsory to prosecute someone who is officially accused of a criminal offence, the exclusion of the same rule in the disciplinary field is reasonable. My experience as Vice-Chairman of the Disciplinary Court of the Consiglio Superiore della Magistratura during the 1998-2002 term is that the system is inherently contradictory and can lend itself to being questioned for its lack of transparency. The issue of what conduct can be seen as being worthy of disciplinary sanction is growing more contentious, and the current state of perplexity is bound to grow when disciplinary violations are not recorded in a written text.

Once again this is a gap which needs to be filled by a discretionary power that may be used leniently or not according to circumstances (eg when dealing with conduct that only shows a lack of sufficient professional standards on the part of the judge, rather than a deliberate breach of duties).

It would be interesting, but impractical here, to scrutinize disciplinary reports of the CSM to see how that body has reacted to the miscellaneous sets of cases it has faced since its formation in 1959.

One certain fact is that a disciplinary code, even if drafted in wide and general terms, could alleviate the hardships now placed on the disciplinary judges' shoulders and might eliminate the risk of inconsistent decisionmaking that hangs over them and casts many doubts as to the efficiency of their judgments.

The third question is deep-rooted in the value of impartiality as a prerequisite for the whole system to retain its credibility in the eyes of the public, and as a goal to be fulfilled in every act of the administration of justice. In particular, the question relates to the feasibility of judges conducting a political career in parallel with their judicial activities. If a judge (or a public prosecutor) is a candidate 
in a political competition should he/she leave his/her office permanently or on a temporary leave? Could he/she compete in a constituency which coincides with the jurisdiction of his/her previous judicial office? And what about the public manifestation of political views by judges and magistrates when in office? Could all this give rise to a suspicion of bias and result in a diminished degree of impartiality?

The memory of pre and post Pinochet (N.2) decisions by the House of Lords as for judicial bias (in particular in Locabail, 2000) cannot fail to impose its weight on this debate. Of course, no magic response to all these questions exists, apart perhaps from the well-known maxim dating back to the 1852 dictum by Lord Campbell in Dimes $v$ Proprietors of Grand Junction Canal according to which "no man should be a judge in his own case" (nemo iudex in re propria). In my view, much emphasis should be placed on (and a great deal of benefit would come from) selfdiscipline and self-restraint, but, on the other hand, the legislator should make his voice heard in this field by, at the very least, laying down a few fundamental guidelines to be observed by all members of the judiciary, backed by varying degrees of criminal sanctions in the event of violation.

\section{JUDGMENTS OF THE EUROPEAN COURT OF JUSTICE}

The second part of this article is devoted to a brief examination of certain judgments by the European Court of Justice, and in particular to two sets of circumstances both related to decisions made by that court. The first, dating back to September 30, 2003 in re Köbler, clearly makes Member States responsible for their own judiciary's violation of any source of European law, such as Directives, once it is established that the violation is committed by a last resort court; that it has as its object a community law disposition involving individual rights; that it is selfevident; and, finally, there is a direct link between the violation itself and the damages suffered by the aggrieved party.

It is perfectly clear that a new form of judicial responsibility - this time towards the state itself - adds to the list of the causes of judicial mishandling of the power every judge makes use of when managing a case. In particular, a presumption seems to have been established according to which no ignorance of community law is to be tolerated on the part of national judges if the unapplied provisions would have put an individual in a better position than he would have been in had they been properly applied. Obviously, this does not result in a thinning of the scope of judicial independence, but it is a robust warning that cannot be unheeded because it calls upon judges' professional training and updating. This approach also, and rightly, takes to its heart the legal protection of individuals living within the European Union.

The second judgment, coming from the Luxembourg Court of Justice was passed at the beginning of October 2004 in re Pfeiffer. In that case an innovative principle was laid down. It was stated that the national judge before whom a dispute between individuals is pending, is bound to consider the national law as a whole in order to interpret and apply it in the light of the European measure and the objective of that measure, so a national provision is chosen that may address itself to the latter. The relevance of the new power conferred upon the national judge concerning the relationship between European and national law should not be understated.

Effectively the national judge should not only be versed in European law, but he is also bound to try and identify a connecting point with the national law in order to bridge any possible gap between the two. Odd though this may seem, I think I am allowed to say that if we are to walk down the road leading to European citizens' rights, we need to build a judiciary whose independence should also be protected outside its national boundaries and inside a new European context. Until the day has come when all necessary conditions are met, it is submitted that it is up to all of us, legal scholars and professionals, to make a contribution in this vital area.

- This article was taken from a lecture given at the Institute of Advanced Legal Studies on May 4, 2005.

\section{Professor Mario Serio}

Professor of Comparative Law, University of Palermo, Italy; Visiting Fellow Institute of Advanced Legal Studies. 